\title{
Gephyrin Is Critical for Glycine Receptor Clustering But Not for the Formation of Functional GABAergic Synapses in Hippocampal Neurons
}

\author{
Sabine Lévi, ${ }^{\star}$ Stephen M. Logan, ${ }^{\star}$ Kenneth R. Tovar, and Ann Marie Craig \\ Department of Anatomy and Neurobiology, Washington University School of Medicine, St. Louis, Missouri 63110
}

\begin{abstract}
The role of the scaffolding protein gephyrin at hippocampal inhibitory synapses is not well understood. A previous study (Kneussel et al., 1999) reported a complete loss of synaptic clusters of the major $\mathrm{GABA}_{\mathrm{A}} \mathrm{R}$ subunits $\alpha 2$ and $\gamma 2$ in hippocampal neurons lacking gephyrin. In contrast, we show here that $\mathrm{GABA}_{A} \mathrm{R} \alpha 2$ and $\gamma 2$ subunits do cluster at pyramidal synapses in hippocampal cultures from gephyrin-Imice, albeit at reduced levels compared with control neurons. Synaptic aggregation of $\mathrm{GABA}_{\mathrm{A}} \mathrm{R} \alpha 1$ on interneurons was identical between the culture types. Furthermore, we recorded miniature IPSCs (mIPSCs) from gephyrin $-/-$ neurons. Although the mean mIPSC amplitude was reduced (by 23\%) compared with control, the frequency of these events was unchanged. Cell surface labeling experiments indicated that gephyrin contributes, in part, to aggregation but not to insertion or stabilization of $\mathrm{GABA}_{\mathrm{A}} \mathrm{R} \alpha 2$ and $\gamma 2$ in the plasma membrane. Thus, a major gephyrin-independent component of hippocampal inhibitory synapse development must exist. We also report that glycine receptors cluster at GABAergic synapses in a subset of hippocampal interneurons and pyramidal neurons. Unlike $\mathrm{GABA}_{\mathrm{A}} \mathrm{Rs}$, synaptic clustering of glycine receptors was completely abolished in gephyrin $-I-$ neurons. Finally, artificial extrasynaptic aggregation of $\mathrm{GABA}_{\mathrm{A}} \mathrm{R}$ was able to redistribute and cocluster gephyrin by a mechanism requiring a neuron-specific modification or intermediary protein. We propose a model of hippocampal inhibitory synapse development in which some $\mathrm{GABA}_{\mathrm{A}} \mathrm{Rs}$ cluster at synapses by a gephyrinindependent mechanism and recruit gephyrin. This clustered gephyrin may then recruit glycine receptors, additional $\mathrm{GABA}_{\mathrm{A}} \mathrm{Rs}$, and other signal-transducing components.
\end{abstract}

Key words: gephyrin; GABA receptor; synaptogenesis; glycine receptor; mIPSC; hippocampal culture

\section{Introduction}

Postsynaptic aggregation of ionotropic neurotransmitter receptors is thought to be essential for synaptic transmission. The mechanisms of postsynaptic clustering of inhibitory $\mathrm{GABA}_{\mathrm{A}}$ receptors $\left(\mathrm{GABA}_{\mathrm{A}} \mathrm{Rs}\right)$ opposite GABAergic terminals are not well understood. Proteins that bind directly to $\mathrm{GABA}_{\mathrm{A}} \mathrm{R}$ subunits include GABARAP and Plic-1 (Kneussel et al., 2000; Bedford et al., 2001; Kittler et al., 2001). Neither of these are tightly colocalized with GABA receptors at postsynaptic sites and, thus, are unlikely to function directly in synaptic aggregation but rather appear to

Received Aug. 22, 2003; revised 0ct. 24, 2003; accepted Nov. 4, 2003.

This work was supported by National Institutes of Health Grants NS33184 and NS34448. We thank Drs. Joshua Sanes and Guoping Feng for the gephyrin mutant mice and for helpful discussions; Drs. Jean-Marc Fritschy and Pietro De Camilli for gifts of antibodies; Drs. Peter Seeburg, Antoine Triller, and Christian Vannier for gifts of cDNAs; and Huaiyang Wu for excellent technical assistance.

*S.L. and S.M.L. contributed equally to this work.

Correspondence should be addressed to Dr. Ann Marie Craig, Department of Anatomy and Neurobiology, Washington University School of Medicine, Box 8108, Room 958, McDonnell Sciences Building, St. Louis, M0 63110. E-mail acraig@pcg.wustl.edu.

S. Lévi's present address: Biologie Cellulaire de la Synapse, Institut National de la Santé et de la Recherche Médicale U497, Ecole Normale Supérieure, Paris, France. E-mail: slevi@wotan.ens.fr.

S. M. Logan's present address: Department of Physiology and Biophysics, Georgetown University Medical Center, Box 571460, 3900 Reservoir Road, Washington, DC 20057. E-mail: slogan1@yahoo.com.

K. R. Tovar's present address: Neurological Sciences Institute, Oregon Health and Science University West Campus, Building 1, 505 Northwest 185th Avenue, Beaverton, OR 97006. E-mail: kentovar@velella.com.

DOI:10.1523/JNEUROSCI.1661-03.2004

Copyright $\odot 2004$ Society for Neuroscience $\quad$ 0270-6474/04/240207-11\$15.00/0 be involved in extrasynaptic trafficking or stabilization of the receptor. Gephyrin, a protein originally identified by copurification with the inhibitory glycine receptor, is tightly colocalized with glycine and $\mathrm{GABA}_{\mathrm{A}} \mathrm{Rs}$ at postsynaptic sites (for review, see Kneussel and Betz, 2000; Sassoe-Pognetto and Fritschy, 2000). Although gephyrin binds the glycine receptor $\beta$ subunit (Meyer et al., 1995), there is no evidence for direct binding of gephyrin to $\mathrm{GABA}_{\mathrm{A}}$ Rs.

In the hippocampus, fast inhibitory synaptic transmission is mediated by $\mathrm{GABA}_{\mathrm{A}} \mathrm{Rs}$. This is in contrast to the cotransmission by glycine and GABA observed in other systems (Jonas et al., 1998; Dumoulin et al., 2001). However, strychnine-sensitive responses to glycine application have been consistently observed in hippocampal neurons (Ito and Cherubini, 1991; Chattipakorn and McMahon, 2002; Thio et al., 2003). Tonic activation of hippocampal glycine receptors by $\beta$-alanine and taurine is thought to modulate fast transmission (Mori et al., 2002). Thus, gephyrin may play a role in modulating glycinergic and/or GABAergic responses in hippocampal neurons.

Genetic targeting in mice and antisense treatment of cultured neurons indicate that gephyrin is essential for formation of postsynaptic glycine receptor clusters in spinal cord neurons (Kirsch et al., 1993; Feng et al., 1998). Furthermore, gephyrin $-/-$ mice die within a few hours after birth and exhibit a rigid, hyperextended posture, similar to wild-type mice treated with the 
glycine receptor antagonist strychnine (Feng et al., 1998). Kneussel et al. (1999) reported a complete absence of clusters of the major $\mathrm{GABA}_{\mathrm{A}} \mathrm{R}$ subunits $\alpha 2$ and $\gamma 2$ in hippocampal cultures from gephyrin $-/-$ mice. Antisense treatment against gephyrin also resulted in a corresponding reduction in density of clusters of $\mathrm{GABA}_{\mathrm{A}} \mathrm{R} \alpha 2$ and $\gamma 2$ in hippocampal cultures (Essrich et al., 1998). Conversely, cortical cultures from $\mathrm{GABA}_{\mathrm{A}} \mathrm{R} \gamma 2-/-$ mice showed a decrease in clustering of gephyrin, suggesting an interdependence of these proteins. Although hippocampal neurons from gephyrin $-/-$ mice exhibit whole-cell currents in response to GABA application (Kneussel et al., 1999), no studies have yet addressed whether GABAergic synaptic responses are affected in the absence of gephyrin.

Here, we assessed the GABAergic synaptic phenotype of hippocampal neurons cultured from gephyrin $-/-$ mice. In direct contrast to previous reports, we observed surface synaptic clusters of $\alpha 1, \alpha 2$, and $\gamma 2$ subunits in gephyrin $-/-$ neurons. Furthermore, GABAergic miniature IPSCs (mIPSCs) were present in hippocampal neurons lacking gephyrin, albeit with a reduced mean amplitude. Surface labeling indicates that gephyrin contributes, in part, to aggregation but not surface insertion or stabilization of $\mathrm{GABA}_{\mathrm{A}} \mathrm{R} \alpha 2$ and $\gamma 2$. Surprisingly, we find that glycine receptors are selectively clustered at GABAergic synapses in a subset of hippocampal neurons and that this clustering is dependent on gephyrin. We also show that artificial aggregation of $\mathrm{GABA}_{\mathrm{A}}$ Rs induces coclustering of gephyrin by a neuron-specific mechanism. Altogether, our results support a novel and substantially gephyrin-independent mechanism of hippocampal inhibitory synapse development.

\section{Materials and Methods \\ Cell culture}

Gephyrin mutant mice, in which the first exon and surrounding sequences responsible for initiating transcription and translation of the gephyrin gene are replaced with the neomycin resistance gene, were a generous gift from Joshua Sanes (Washington University, St. Louis, MO) (Feng et al., 1998). Gephyrin mutant mice were maintained as heterozygotes in a C57BL/6 background. Cultures were prepared from individual P0 mice pups. Genotype was determined by PCR of tail tissue (Feng et al., 1998). Gephyrin expression phenotype was also confirmed by immunocytochemistry of cultured neurons.

Cultures were prepared from hippocampal neurons using described methods (Goslin et al., 1998). Briefly, hippocampi were dissected from P0 mouse pups or E18 rat embryos and dissociated using papain (20 $\mathrm{U} / \mathrm{ml})$ or trypsin $(0.25 \%)$ and trituration. Neurons were plated at a final density of $1-5 \times 10^{5}$ cells/dish on poly-L-lysine-coated coverslips in 60 $\mathrm{mm}$ culture dishes in MEM supplemented with $10 \%$ horse serum. After 2-4 hr, coverslips were inverted over an astroglial feeder layer in serumfree MEM with $\mathrm{N} 2$ supplements, $0.1 \%$ ovalbumin, and $1 \mathrm{mM}$ pyruvate (N2.1 media; components from Invitrogen, Carlsbad, CA). The neurons grew face down over the feeder layer but were kept separate from the glia by wax dots on the neuronal side of the coverslips. To prevent the overgrowth of the glia, neuron cultures were treated with cytosine arabinoside ( $5 \mu \mathrm{M}$; Calbiochem, La Jolla, CA) after $3 \mathrm{~d}$ in vitro (DIV). Cultures were maintained in N2.1 media for up to 3 weeks, feeding the cells once per week by replacing one-third of the media per dish. APV (100 $\mu \mathrm{M}$; Research Biochemicals, Natick, MA) was added twice per week to the cultures beginning at 7 DIV. Mouse neurons were used for Figures 1-6, and rat neurons for Figures 6-8. CHO-K1 and COS-7 cell lines were obtained from American Type Culture Collection (Manassas, VA).

\section{Electrophysiology}

Spontaneous mIPSCs were recorded from neurons at 11-16 DIV at room temperature in the whole-cell voltage-clamp configuration. The extracellular solution contained (in $\mathrm{mm}$ ): $168 \mathrm{NaCl}, 2.4 \mathrm{KCl}, 10$ HEPES, 10 D-glucose, $1.3 \mathrm{CaCl}_{2}$, and $1.3 \mathrm{MgCl}_{2}, \mathrm{pH}$ 7.4. mIPSCs were recorded in the presence of $0.5 \mu \mathrm{M}$ TTX, $5 \mu \mathrm{M}$ 2,3 dioxo-6-nitro-1,2,3,4tetrahydrobenzo[f]quinoxaline-7-sulfonamide (NBQX), and $100 \mu \mathrm{M}$ APV. Electrodes were pulled from borosilicate glass and filled with solution containing (in mM): $144 \mathrm{CsCl}_{2}, 10 \mathrm{HEPES}, 5 \mathrm{Na}_{2} \mathrm{ATP}, 1.1$ EGTA, 0.1 $\mathrm{CaCl}_{2}$, and $5 \mathrm{MgCl}_{2}, \mathrm{pH} 7.4$, with the addition of $5 \mathrm{mg} / \mathrm{ml}$ neurobiotin, as indicated. Neurons were voltage clamped at $-70 \mathrm{mV}$. Recordings were performed with an Axopatch 1D amplifier and Axograph software (Axon Instruments, Foster City, CA). Records were filtered at $5 \mathrm{kHz}$ and acquired at $10 \mathrm{kHz}$. Series resistance values were $<10 \mathrm{M} \Omega$, input resistance $>180 \mathrm{M} \Omega$, and RMS noise $<5.5$ pA. mIPSCs were detected with Axograph software event detection using an optimally scaled sliding template (Clements and Bekkers, 1997) and criteria of three times the SD, a rise time of $0.1-2.5 \mathrm{msec}$, and a half-width of $\geq 2 \mathrm{msec}$. The range of mIPSC peak amplitudes detected was -11.3 to -282.5 pA. For most experiments, only cells with $\geq 50$ events were included in the analysis. However, for the data presented in Figure 7, even cells with a lower number of events were included because these may represent cells with minimal sites of GABAergic innervation.

\section{Immunocytochemistry}

Total receptor. Neurons were fixed for $15 \mathrm{~min}$ in warm PBS with $4 \%$ paraformaldehyde and $4 \%$ sucrose and permeabilized with $0.25 \%$ Triton $\mathrm{X}-100$. For glycine receptor staining, neurons were fixed for $20 \mathrm{~min}$ in paraformaldehyde and then incubated in methanol $\left(15 \mathrm{~min},-20^{\circ} \mathrm{C}\right)$. The neurons were incubated in $10 \% \mathrm{BSA}$ for $30 \mathrm{~min}$ at $37^{\circ} \mathrm{C}$ to block nonspecific staining and incubated in appropriate primary antibody $(\mathrm{Ab})\left(1 \mathrm{hr} ; 37^{\circ} \mathrm{C}\right)$. After washing in PBS, cells were incubated in secondary $\mathrm{Ab}\left(45 \mathrm{~min} ; 37^{\circ} \mathrm{C}\right)$. The coverslips were mounted in elvanol (Tris$\mathrm{HCl}$, glycerol, and polyvinyl alcohol with $2 \%$ 1,4-diazabicyclo[2,2,2] octane).

Surface receptor. Neurons were incubated $15 \mathrm{~min}$ at room temperature in primary Ab diluted in N2.1 media from the host dish with the addition of HEPES buffer (50 mM; pH 7.4). Cells were rinsed using fresh N2.1 media with HEPES buffer, returned to their home dishes for $30 \mathrm{~min}$, and then fixed in paraformaldehyde. In the cross-linking experiments, after primary $\mathrm{Ab}$ and washing, cells were incubated in biotinylated anti-guinea pig $\mathrm{Ab}$ (10 min at room temperature). Coverslips were then either returned to their host dishes for $12 \mathrm{hr}$ (T12), after which they were rinsed and incubated in Alexa488 streptavidin, or this procedure was performed immediately (T0). After surface labeling, cells were permeabilized and processed for GAD, synapsin, or gephyrin immunodetection with appropriate Ab.

Antibodies. Primary antibodies were: guinea pig anti-GABA ${ }_{\mathrm{A}} \mathrm{R} \alpha 1, \alpha 2$, and $\gamma 2$ subunits (1:2000 total or 1:1000 surface; generously supplied by Dr. J. M. Fritschy, University of Zurich, Zurich, Switzerland); mouse anti-gephyrin (mAb7a; IgG1; 1:200; Alexis, San Diego, CA), anti-GAD (GAD6; supernatant; IgG2a; 1:50; Developmental Studies Hybridoma Bank, Iowa City, IA), and anti-glycine receptor $\alpha$ and $\beta$ subunits (mAb4a; IgG1; 1:100; Alexis) (this recognizes aa 96-105 of rat glycine receptor $\alpha 1$, which is conserved in other glycine but not GABA receptor subunits) (Schroder et al., 1991); rabbit anti-synapsin (1:500; Chemicon, Temecula, CA); anti-SynGap (1:1000; Affinity Bioreagents, Golden, CO); human anti-gephyrin (CSF861; supernatant; 1:500; a gift from Dr. P. De Camilli, Yale University, New Haven, CT); and biotinylated goat anti-green fluorescent protein (GFP) (1:200; Rockland Immunochemicals, Gilbertsville, PA). Secondary antibodies were: Alexa488 anti-guinea pig Ab [whole IgG (1:200) and Fab fragment (1:50)], Alexa594 antiguinea pig $\mathrm{Ab}$ (1:200); Alexa350 anti-mouse IgG2A (1:100), Alexa488 anti-mouse IgG1 (1:500), Alexa568 anti-mouse IgG1 (1:500), Alexa594 anti-mouse IgG2A (1:200), Alexa647 anti-mouse IgG2a (1:100), and Alexa488 streptavidin (1:200) (all from Molecular Probes, Eugene, OR) (the Fab fragment was generated using the Immunopure Fab kit from Pierce, Rockford, IL); FITC anti-human Ab (1:1000); aminomethylcoumarin (AMCA) anti-rabbit $\mathrm{Ab}(1: 100)$; biotinylated anti-guinea pig $\mathrm{Ab}$ (1:200); and AMCA streptavidin (1:100) (from Jackson Immunochemicals, West Grove, PA; or Vector Laboratories, Burlingame, CA).

\section{Fibroblast cross-linking}

Rat gephyrin cDNA (2,6 isoform) was a gift from A. Triller and C. Vannier (Ecole Normale Supérieure, Paris, France) (Meier et al., 2000). It was 
subcloned for expression into pECFP-N1 (Clontech, Palo Alto, CA) either as an $\mathrm{N}$-terminal fusion with cyan fluorescent protein (CFP) and a glycine-valine linker or untagged. pRK5 expression plasmids for rat GABAR subunits were a gift from P. Seeburg (Max Planck Institut, Heidelberg, Germany) (Seeburg et al., 1990). The mature $\alpha 2$ coding region was fused at its $\mathrm{N}$ terminus to the signal peptide of NMDAR2B fused to enhanced yellow fluorescent protein (EYFP) in the pEYFP-N1 vector to express YFP- $\alpha 2$. Mouse GABARAP cDNA was obtained from American Type Culture Collection. It was expressed untagged from pEYFP-N1 or tagged at the $\mathrm{N}$ terminus with the 10 aa myc epitope, followed by a linker LNGGGGGST from pRK5. Constructs were transfected into COS-7 or CHO-K1 cells using Effectene (Qiagen, Valencia, CA) or Lipofectamine 2000 (Invitrogen) over a range of total amounts and ratios of plasmids. At 1-2 d after transfection, surface GABAR was cross-linked by exposure of live cells to biotinylated anti-GFP antibody, followed by AMCA-streptavidin.

\section{Image analysis}

For Figure 5B, images were acquired using an Olympus FV500 confocal laser-scanning microscope. All other fluorescence and phase contrast images were acquired with a Photometrics Sensys cooled CCD camera on a Axioskop microscope (Zeiss, Oberkochen, Germany) with a $63 \times, 1.4$ numerical aperture objective using Metamorph software (Universal Imaging, West Chester, PA) for analysis. Sets of neurons compared for quantitation were stained simultaneously. Neurons for imaging were chosen from random areas of each coverslip based on phase contrast showing healthy morphology and the distribution of presynaptic markers (GAD, synapsin) showing innervation and imaged using the same exposure time. Images were randomized for blind quantitation.

For quantitation, the images were first background subtracted by a dark-field image and flatfield divided to correct for any nonuniformity in illumination. For each image, a region of interest was chosen based on the phase contrast channel encompassing $\sim 150-300 \mu \mathrm{m}$ length from one to two dendrites of moderate diameter. We thresholded the channels of each image so that puncta (corresponding to receptors, gephyrin, or presynaptic markers) were approximately twofold greater in intensity than the diffuse fluorescence on the dendritic shaft within the region of interest. In the mouse cultures, we selected dendrites that were innervated by GAD and thresholded for puncta on the receptor image as described above. Values in Figure 4 represent the integrated surface receptor immunofluorescence intensity in clusters as a percentage of the integrated intensity for the whole dendrite region. For Figure 7, the several high-resolution images covering the somtatodendritic domain of the neurobiotin-filled cell were combined into a single image before quantitation. Synaptic receptors were measured using a combination of thresholding at approximately twofold the dendritic shaft intensity and manually tracing all regions of interest containing receptor puncta opposed to GAD along all dendrites. The cell body regions were excluded from analysis because of high background staining. For Figure 8, synaptic receptor/ gephyrin puncta were determined by measuring the number of thresholded receptor/gephyrin clusters under a binary mask of the thresholded synapsin image. The percentage of $\mathrm{GABA}_{\mathrm{A}} \mathrm{R} \alpha 2$ clusters colocalized with gephyrin corresponds to the percentage of thresholded $\mathrm{GABA}_{\mathrm{A}} \mathrm{R}$ puncta overlapping with a binary mask of the gephyrin image. Analysis was performed using Metamorph, Microsoft Excel, StatView, and CricketGraph. All statistical comparisons of immunofluorescence were made using Student's $t$ test. Images were prepared for printing using Adobe Photoshop.

\section{Results}

mIPSCs in gephyrin-/- hippocampal neurons

Whole-cell voltage-clamp recordings were done on hippocampal neurons cultured for 11-16 d from individual gephyrin -/- and wild-type littermate pups (Fig. 1). To isolate mIPSCs, recordings were done in solutions containing NBQX $(5 \mu \mathrm{M})$, APV $(100 \mu \mathrm{M})$, and TTX $(0.5 \mu \mathrm{M})$. GABA $\mathrm{A}$-mediated mIPSCs were observed in wild-type and gephyrin $-/-$ neurons and were blocked by bicuculline methiodide $(10 \mu \mathrm{M})$ or SR95531 $(10 \mu \mathrm{M})$. The mean
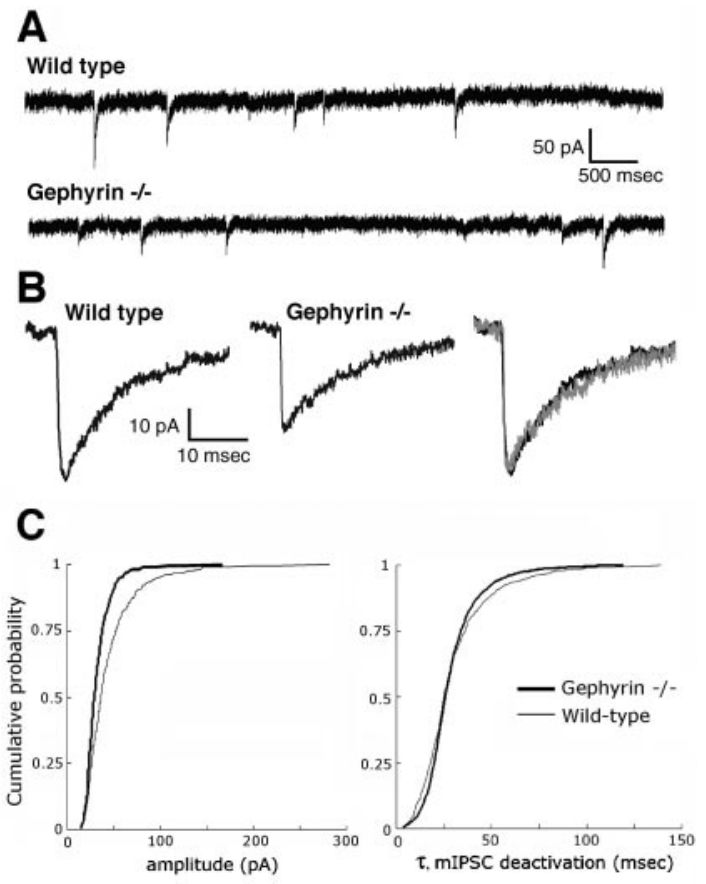

Figure 1. Properties of GABAergic miniature synaptic currents in gephyrin mutant hippocampal neurons. mIPSCs were evident in gephyrin $-/-$ and gephyrin $+/+$ neurons $(A)$. The averaged events from each cell in $A$ are shown in $B$, scaled at the right, with the gephyrin $-1-$ trace in gray. The cumulative probability distributions of events pooled from all cells ( $n \geq 350$ events; $\leq 50$ events per cell) showed a difference in amplitude distribution between gephyrin $-/-$ and gephyrin $+/+$ groups $(C ; K-S ; p<0.001)$ but no difference in decay time constant $(p>0.1)$.

mIPSC amplitude from wild-type neurons was $-42.7 \pm 4.4 \mathrm{pA}$ ( $n=9$ cells), whereas the mean mIPSC amplitude from gephyrin $-/-$ neurons was $-33.0 \pm 2.6 \mathrm{pA}(n=9)$ [KolmogorovSmirnov (K-S) test; $p<0.05]$. Furthermore, the distributions of mIPSC amplitudes from wild-type and gephyrin-/- neurons were different (Fig. 1C) (K-S; $p<0.001)$. This seemed to result from a selective loss of higher amplitude events in the gephyrin $-/-$ neurons. No difference was detected in the frequency of mIPSCs between groups (wild-type interevent interval, $3.7 \pm 1.3$ sec; gephyrin $-/-$ interevent interval, $5.3 \pm 1.2 \mathrm{sec} ; n=9$ each; $\mathrm{K}-\mathrm{S} ; p>0.1)$, nor could we detect a difference in the distributions of mIPSC deactivation kinetics (Fig. $1 C$ ) (K-S; $p>0.1$ ). Thus, the mean amplitude of mIPSCs from neurons that lacked gephyrin was reduced compared with wild-type controls.

\section{Synaptic clustering of $\mathrm{GABA}_{\mathrm{A}} \mathrm{Rs}$ in gephyrin-/- hippocampal neurons}

Hippocampal neurons from wild-type, gephyrin +/-, or gephyrin- - P0 littermates were cultured for 2 weeks and immunolabeled for combinations of gephyrin, $\mathrm{GABA}_{\mathrm{A}} \mathrm{R} \alpha 1, \alpha 2$, or $\gamma 2$, and the presynaptic markers synapsin and GAD (the synthetic enzyme that labels GABAergic terminals). The genotype of all gephyrin-/- neurons was confirmed by the absence of detectable gephyrin immunoreactivity (Fig. 2). Even in the absence of gephyrin, clusters of all $\mathrm{GABA}_{\mathrm{A}} \mathrm{R}$ subunits assayed were detected, both by cell surface labeling and by permeabilized cell labeling. By quantitative measures, which may yield a low estimate because some clusters may fall below threshold, a similar percentage of $\mathrm{GABA}_{\mathrm{A}} \mathrm{R}$ clusters exhibited overlap with synapsin puncta in gephyrin $-/-$ cultures $(64 \pm 7 \%)$ as in wild-type cultures (72 \pm $4 \%$ ) (Lévi et al., 2002). Furthermore, the surface $\mathrm{GABA}_{\mathrm{A}} \mathrm{R}$ clus- 
ters were apposed to GAD-labeled terminals (Fig. 3). Thus, GABA $\mathrm{A}_{\mathrm{A}}$ clusters can form at synapses opposite GABAergic terminals in neurons lacking gephyrin. Note that images in Figure 3 represent cells with relatively strong receptor clustering, to emphasize that this can occur for all genotypes. However, the extent of receptor clustering in the populations of cells was not equal among genotypes, as shown in Figure 4.

Clustering of the major $\mathrm{GABA}_{\mathrm{A}} \mathrm{R}$ subunits $\alpha 2$ and $\gamma 2$ appeared to be less pronounced in the gephyrin-/- neurons. This observation was confirmed by quantitation of random sets of pyramidal cells compared with littermate gephyrin +/controls (Fig. 4). On average, there was a $65 \%$ decrease in the percentage of surface $\alpha 2$ immunofluorescence present in clusters and a $43 \%$ decrease in surface $\gamma 2$ present in clusters in gephyrin- - neurons compared with controls ( $t$ test; $p<$ $0.001 ; n \geq 40$ cells from at least four animals of each genotype from two independent cultures). A similar decrease was found in synaptic aggregation in permeabilized cells labeled for total $\alpha 2$ in the gephyrin mutant compared with control (Fig. 4). The reduction in percentage of clustered $\mathrm{GABA}_{\mathrm{A}} \mathrm{R}$ as measured this way could reflect a reduction in number, size, or mean intensity of clusters. We found no significant difference in cluster size or intensity $(p>0.05)$ but a significant difference in the number of clusters per dendrite length $(p<0.05$; the mean reduction in cluster number per dendrite length was $48 \%$ for $\alpha 2$ and $36 \%$ for $\gamma 2$ ). This finding could reflect either a real loss of a subset of receptor clusters, or a reduction of the density of receptors at a large fraction of clusters such that these postsynaptic sites would no longer pass the twofold intensity threshold needed to be counted as a cluster. No difference was observed between wild-type and gephyrin $+/-$ neurons in the patterns of immunoreactivity for any $\mathrm{GABA}_{\mathrm{A}} \mathrm{R}$ subunits (Figs. 2, 3). This was confirmed by quantitation of $\alpha 2$ in another set of sister cultures (percentage of clustered $\alpha 2$ was $5.8 \pm 0.7 \%$ for $+/+$ and $5.1 \pm 2.4 \%$ for gephyrin $+/-$; $p>0.1 ; n=27$ cells from two independent cultures).

The $\mathrm{GABA}_{\mathrm{A}} \mathrm{R} \alpha 1$ subunit is expressed only by a subset of hippocampal neurons and is particularly strongly expressed by interneurons (Brunig et al., 2002a). Gephyrin is equally highly expressed at GABAergic synaspes in both pyramidal neurons and interneurons and coclusters with $\mathrm{GABA}_{\mathrm{A}} \mathrm{R} \alpha 1, \alpha 2$, and $\gamma 2$ subunits (data not shown). Quantitation of surface $\alpha 1$ on interneurons revealed no defects of synaptic aggregation in gephyrin-/neurons compared with controls (Fig. 4). Thus, gephyrin is only partially required for synaptic clustering of $\mathrm{GABA}_{\mathrm{A}} \mathrm{R} \alpha 2$ and $\gamma 2$ and not required at all for localization of $\alpha 1$.

We tested whether the defect in localization of $\alpha 2$ and $\gamma 2$ in gephyrin $-/-$ neurons is attributable to a deficit in trafficking to the cell surface or a specific deficit in synaptic aggregation. There was no decrease in the total amount of $\alpha 2$ or $\gamma 2$ on the dendrite surface of gephyrin $-/-$ neurons compared with controls [the mean dendrite surface fluorescence intensity averaged over a large area in arbitrary units was $482 \pm 20$ for gephyrin-/- neurons and $468 \pm 22$ for controls for $\alpha 2$, and $917 \pm 21$ for gephyrin $-/-$ neurons and $859 \pm 21$ for controls for $\gamma 2(p>0.1 ; n \geq$ $40)$, measured from the same cells and dendrite regions quantitated for Fig. 4]. Furthermore, surface labeling, followed by permeabilization and labeling for total cell $\mathrm{GABA}_{\mathrm{A}} \mathrm{R} \alpha 2$ did not reveal any additional aggregated intracellular pools (Fig. $5 A$ ). Cell surface labeling was also confirmed by confocal microscopy, which showed $\mathrm{GABA}_{\mathrm{A}} \mathrm{R} \alpha 2$ clusters following GAD-labeled axons through different optical sections up the surface of somata (Fig. 5B). A similar pattern of surface labeling was seen using guinea pig anti-GABA $\mathrm{A} \alpha 2 \mathrm{Ab}$, followed by Alexa488conjugated anti-guinea pig Fab on live cells (data not shown). Thus gephyrin-/- hippocampal neurons are partially deficient in synaptic aggregation but not in surface trafficking of $\mathrm{GABA}_{\mathrm{A}} \mathrm{R}$ $\alpha 2$ and $\gamma 2$.

Finally, quantitation of the percentage of dendrite area innervated by GAD-immunopositive axons revealed no difference be- 

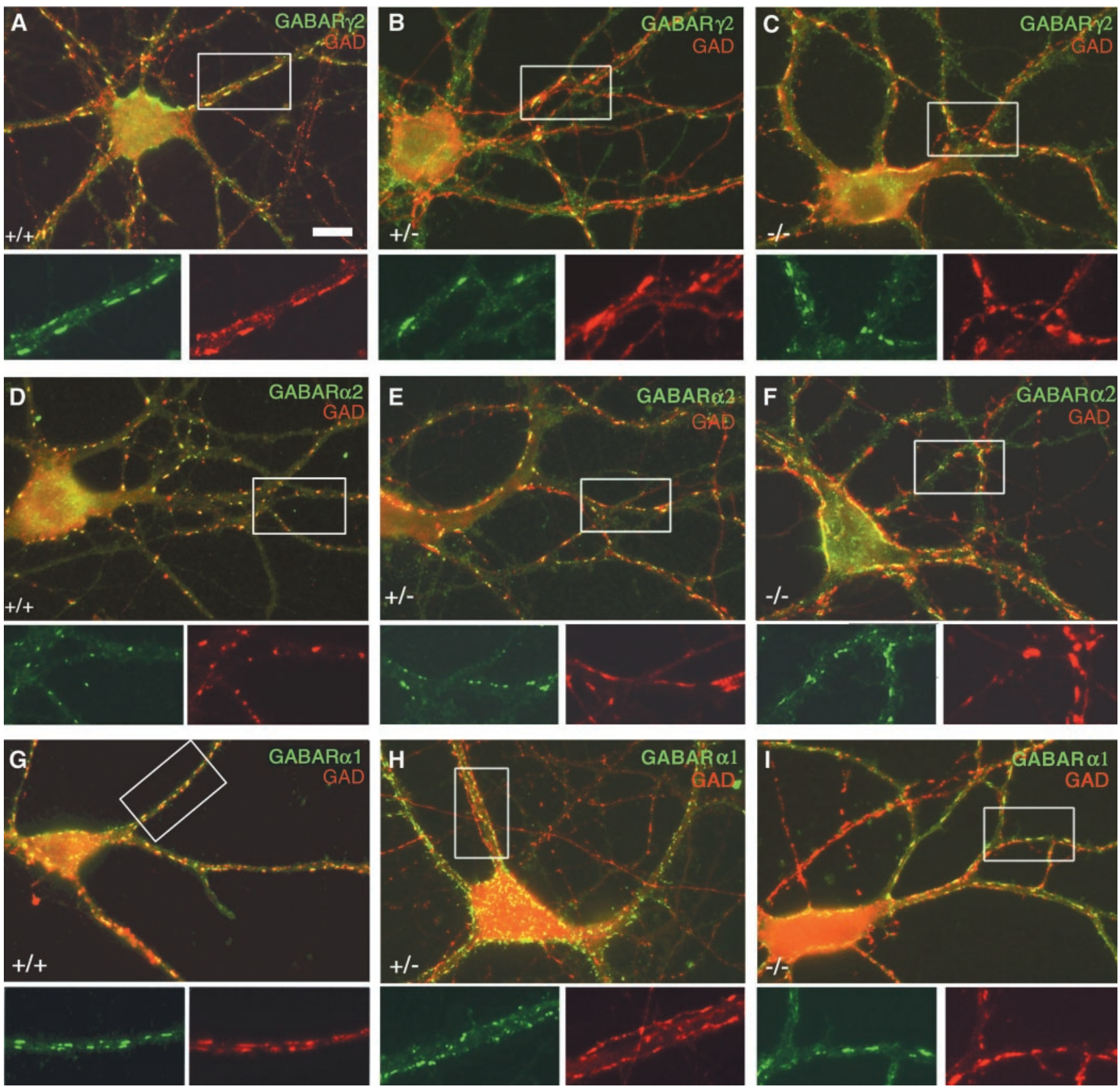

Figure 3. Synaptic localization of $G A B A_{A} R$ subunits in gephyrin mutant neurons. Surface $G A B A_{A} R \gamma 2(A-C$, green), $\alpha 2$ (D-F, green), and $\alpha 1$ (G-I, green) subunits were clustered opposite GABAergic terminals labeled with $G A D$ (red) in all genotypes [gephyrin $+/+(A, D, G)$, gephyrin $+/-(B, E, H)$, and gephyrin $-I-(C, F, J)$ ]. Interneurons, identified by high levels of $G A D$ in the soma, were analyzed for $\alpha 1(G-l)$, and pyramidal neurons for $\gamma 2(A-C)$ and $\alpha 2(D-F)$. Boxed regions in the double-color images are shown as enlarged single-channel images below. These images represent some of the most highly clustered receptor distributions for all genotypes. Scale bar, $10 \mu \mathrm{m}$.

tween gephyrin $-/-$ and control neurons $(14.1 \pm 1.0 \%$ for gephyrin $+/-$ vs $15.4 \pm 1.3 \%$ for gephyrin $-/-; n \geq 36$ cells; $p>$ 0.1 ). Thus, the reduction in clustering of surface $\mathrm{GABA}_{\mathrm{A}} \mathrm{R} \alpha 2$ and $\gamma 2$ was not caused by any reduction in GABAergic innervation in the absence of gephyrin. Using light microscopy, we could detect no defects in presynaptic differentiation of GABAergic synapses in the absence of gephyrin.

\section{Synaptic clustering of glycine receptors in hippocampal} neurons and dependence on gephyrin

Hippocampal neurons have surface glycine receptors as shown by strychnine-sensitive responses to glycine application (Ito and
Cherubini, 1991). Using an Ab that recognizes all glycine receptor subunits (MAb4a), we could detect glycine receptors in a subset of hippocampal neurons (Fig. 6). Surprisingly, these glycine receptors consistently clustered at GABA synapses, as indicated by double labeling of glycine receptor with GAD, gephyrin, or GABAR (Fig. 6A-D). There were additional clusters of GABAR and gephyrin that lacked detectable glycine receptor. Glycine receptor clustering was observed on a subset of both pyramidal neurons and interneurons (Fig. 6E,F). Quantitation at 3 weeks in culture revealed glycine receptor clustering on $72 \%$ of interneurons and only $41 \%$ of pyramidal neurons (identified by GAD immunoreactivity or lack thereof). Glycine receptor clus- 


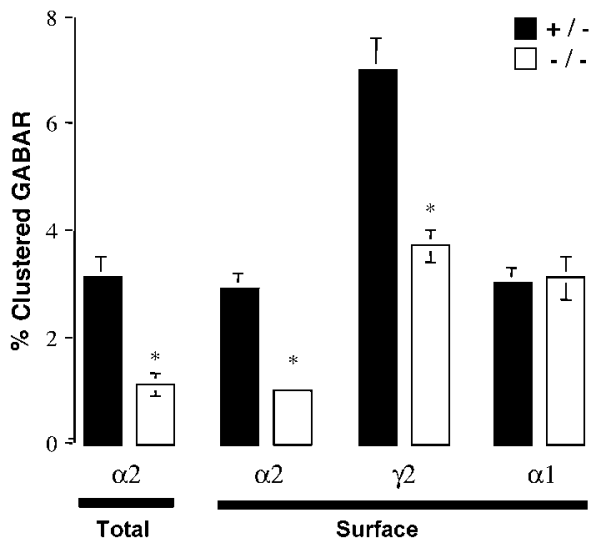

Figure 4. Levels of clustered $G_{A B A} A_{A}$ subunits in gephyrin mutant neurons. GAD-innervated dendrites were measured for surface or total cell $G A B A_{A} R$ subunit immunofluorescence (see Materials and Methods). The percentage of receptor fluorescence present in aggregates was reduced in the gephyrin $-/-$ neurons compared with gephyrin $+/-$ controls for $\alpha 2$ and $\gamma 2$ but not $\alpha 1$ ( $^{*} p<0.001$; values represent integrated fluorescence in clusters as a percentage of integrated fluorescence of the whole dendrite region).

tering could be observed as early as 1 week in culture, but, at this stage, receptor clusters were smaller and were detected only on $13 \%$ of cells with GAD innervation.

Glycine receptor clustering on hippocampal neurons was essentially abolished in the absence of gephyrin. Only $2.5 \%$ of cells showed any glycine receptor clusters in cultures from gephyrin $-/-$ mice compared with $44 \%$ in control littermate cultures (Fig. 6G,H). Thus, gephyrin is essential for clustering of glycine receptors but not GABARs at inhibitory synapses on hippocampal neurons.

\section{Comparison of mIPSC and synaptic GABAR cluster distributions on wild-type neurons}

The apparent deficit in synaptic aggregation of the major $\mathrm{GABA}_{\mathrm{A}} \mathrm{R}$ subunits was more pronounced than the deficit in $\mathrm{mIP}$ SCs described above. This prompted us to investigate the relationship between mIPSCs and synaptic GABAR clusters in wildtype neurons. mIPSCs were recorded in the whole-cell voltageclamp configuration with neurobiotin in the pipette. The cells were fixed immediately after recording and immunolabeled for $\mathrm{GABA}_{\mathrm{A}} \mathrm{R} \alpha 2, \mathrm{GAD}$, and avidin to identify the recorded cell. The cells for analysis were labeled in one batch and imaged with identical camera settings so that GABAR immunofluorescence intensity levels could be directly compared. When two cells toward the extremes of the population were compared, there appeared to be a relationship between distribution of mIPSC amplitude and distribution of synaptic $\mathrm{GABA}_{\mathrm{A}} \mathrm{R} \alpha 2$ cluster intensity values (total integrated intensity per cluster). Cell $29 \mathrm{~F}$ had the highest mean cell mIPSC amplitude and showed a greater skew toward high values for both mIPSC amplitude and synaptic $\mathrm{GABA}_{\mathrm{A}} \mathrm{R} \alpha 2$ cluster intensity compared with cell 29C (Fig. $7 A, B$ ). However, comparison of the whole set of eight sister cells indicated no significant correlation between mean cell mIPSC amplitude and mean cell synaptic $\mathrm{GABA}_{\mathrm{A}} \mathrm{R} \alpha 2$ cluster intensity (Fig. 7C) $(p>0.1$; Spearman's correlation test). Following the approach of Nusser et al. (1997) and Frerking et al. (1995), we also compared the shapes of the distributions of mIPSC amplitude and receptor immunofluorescence by normalizing values to the mean and SD $($ Fig. $7 D)[$ standardized value $=($ value - mean $) / S D]$. The distributions of the pooled standardized mIPSC values were not significantly different from the pooled standardized GABAR immu- nofluorescence values (Fig. 7D) (K-S; $p>0.1)$. Even when performed on a single-cell basis, all cells showed no significant difference in these distributions $(p>0.05$ for all). These results suggest that a relationship may exist between mIPSC amplitude and synaptic GABAR immunofluorescence. However, the degree of similarity in shape of the mIPSC and GABAR immunofluorescence distributions and, thus, the strength of the relationship between them, varied among individual cells (K-S; $p=0.09$ to $p>0.99)$.

\section{Coclustering of gephyrin induced by artificial aggregation of GABAR}

Aggregates of gephyrin in heterologous cells do not cocluster most $\mathrm{GABA}_{\mathrm{A}} \mathrm{R}$ subunits, with the exception of partial coclustering of $\mathrm{GABA}_{\mathrm{A}} \mathrm{R} \beta 3$ (Kirsch et al., 1995). Here, we asked whether aggregation of $\mathrm{GABA}_{\mathrm{A}} \mathrm{R}$ could induce coclustering of gephyrin in neurons. Surface aggregation of GABAR was artificially induced by exposure of living neurons to anti-GABAR $\alpha 2$ antibodies, followed by divalent secondary antibodies (Fig. $8 A-D$ ). This resulted in the formation of numerous small extrasynaptic GABAR puncta, presumably by aggregation of the normally diffuse extrasynaptic surface receptor pool. On initial formation, these extrasynaptic receptor aggregates lacked associated gephyrin (Fig. $8 \mathrm{~B})$. However, if the neurons were maintained for another $12 \mathrm{hr}$ before fixing, gephyrin became associated with these extrasynaptic GABARs (Fig. $8 C$ ). These results are reflected quantitatively in the decrease in percentage of gephyrin clusters that are synaptic and the increase in percentage of receptor clusters colocalizing with gephyrin, between time T0 and T12 hr (Fig. 8D). Thus, artificial aggregation of GABARs induces redistribution and coclustering of gephyrin to the extrasynaptic GABAR clusters. Danglot et al. (2003) also report the presence of some native extrasynaptic $\mathrm{GABA}_{\mathrm{A}} \mathrm{R}$-gephyrin coclusters in hippocampal neurons.

To determine whether this apparent association between extrasynaptic $\mathrm{GABA}_{\mathrm{A}} \mathrm{R}$ and gephyrin is direct or indirect, we coexpressed $\mathrm{GABA}_{\mathrm{A}} \mathrm{R}$ YFP- $\alpha 2, \beta 3, \gamma 2$, and gephyrin or CFP-gephyrin in fibroblasts and performed a similar cross-linking experiment. In contrast to the result in neurons, surface clustering of transfected $\mathrm{GABA}_{\mathrm{A}} \mathrm{R}$ in fibroblasts yielded no detectable coclustering of gephyrin (Fig. 8E,F). Gephyrin maintained separate aggregates and even the diffuse gephyrin did not associate with the GABAR clusters. Thus, a neuron-specific component, either an intermediate protein or modification of gephyrin or GABAR, is necessary for the association. Because GABARAP is reported to bind both $\mathrm{GABA}_{\mathrm{A}} \mathrm{R} \gamma 2$ and gephyrin (Kneussel et al., 2000; Nymann-Andersen et al., 2002), we also tried coexpressing GABARAP or myc-GABARAP along with GABAR and gephyrin. However, although COS and $\mathrm{CHO}$ cells coexpressing GABAR, myc-GABARAP, and gephyrin or CFP-gephyrin were observed, we never observed gephyrin coclustering with GABAR in the surface cross-linking assay (data not shown). These finding suggest that some neuron-specific modification or intermediate other than GABARAP is necessary for association of gephyrin and GABAR in neurons.

\section{Discussion}

We report here the role of gephyrin in inhibitory synaptogenesis in hippocampal neurons. Gephyrin - / - neurons exhibited mIPSCs at normal frequency but reduced amplitude (23\% reduction in mean amplitude), an unexpected finding considering that a previous study reported a complete absence of $\mathrm{GABA}_{\mathrm{A}} \mathrm{R}$ clusters in hippocampal neurons from gephyrin-/- mice (Kneussel et al., 1999). We further detected cell surface synaptic clusters of 


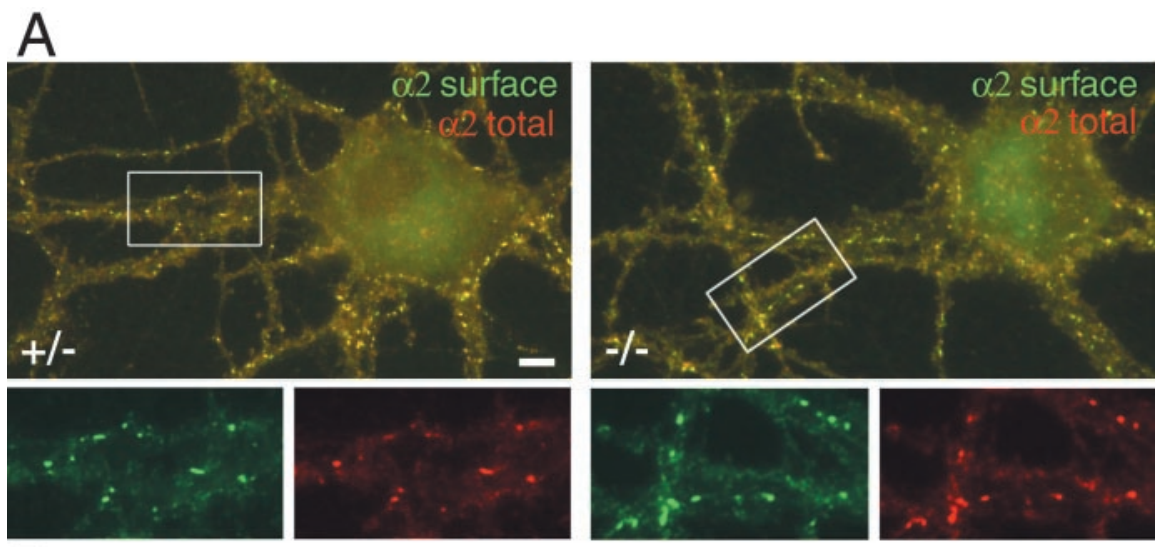

B Gephyrin -/-

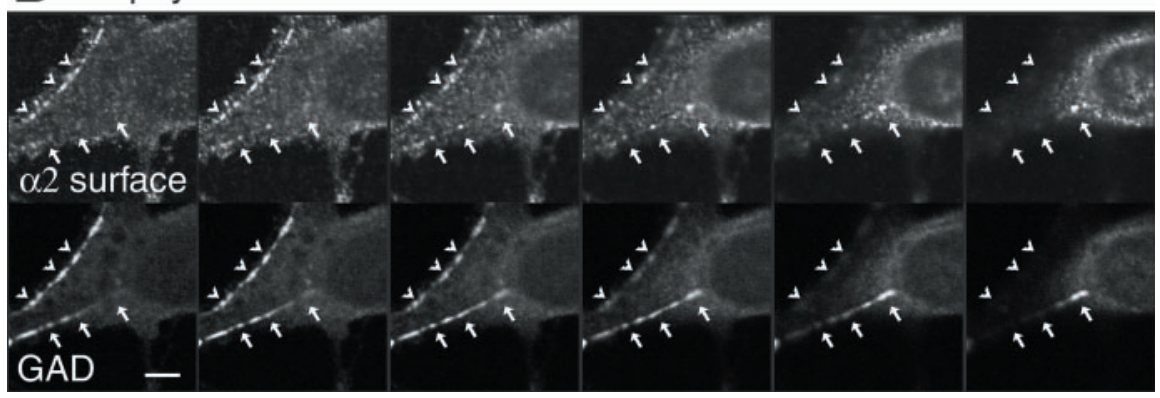

Figure 5. Surface localization of $\mathrm{GABA}_{\mathrm{A}} \mathrm{Rs}$ in gephyrin mutant neurons. $A$, Neurons were labeled live with $\alpha 2 \mathrm{Ab}$, fixed and permeabilized, incubated with secondary Ab (green), then incubated again with $\alpha 2 \mathrm{Ab}$ and new secondary Ab (red). Thus, surface receptor labels with both color secondary $A b$ (because all sites were not saturated), whereas internal receptor labels with red secondary $A b$ only. Internal aggregates of $G A B A_{A} R$ were not observed in any genotype. $B$, Surface association of $G A B A_{A} R$ was confirmed by confocal microscopy. Shown are a series of optical sections from a plane near the substrate following up the surface of a thick dendrite and soma. The receptor clusters are in the same optical sections as the GAD-labeled axons on the cell surface. Scale bars: $A, 10 \mu \mathrm{m} ; B, 5 \mu \mathrm{m}$.

$\mathrm{GABA}_{\mathrm{A}} \mathrm{R} \alpha 1, \alpha 2$, and $\gamma 2$ subunits on hippocampal neurons from gephyrin-/- mice. Compared with wild-type neurons, synaptic aggregation of $\mathrm{GABA}_{\mathrm{A}} \mathrm{R} \alpha 2$ and $\gamma 2$ on pyramidal neurons lacking gephyrin was reduced (by 65 and 43\%, respectively). This was because of a specific defect in synaptic aggregation with no reduction in receptor trafficking to the surface. There was no deficit in synaptic clustering of $\mathrm{GABA}_{\mathrm{A}} \mathrm{R} \alpha 1$ subunit on gephyrin -/- interneurons. We also report here the novel finding that glycine receptors are clustered at GABA synapses in a subset of hippocampal neurons. In contrast to the relative independence of GABARs on gephyrin, glycine receptor clustering at inhibitory synapses was completely dependent on gephyrin. Finally, we show that artificial aggregation of GABARs at extrasynaptic sites induces coclustering of gephyrin via a neuron-specific intermediate protein. Thus, it may be that GABARs induce localization of gephyrin and glycine receptors to hippocampal inhibitory synapses. Altogether, these results indicate the existence of a major gephyrin-independent pathway for synaptic aggregation of GABARs and development of functional inhibitory synaptic currents in hippocampal neurons.

\section{Role of gephyrin in synaptic clustering of $\mathrm{GABA}_{\mathrm{A}} \mathrm{Rs}$}

Our results indicate a greater degree of synaptic clustering of $\mathrm{GABA}_{\mathrm{A}} \mathrm{R}$ subunits in hippocampal neurons from gephyrin-1mice than that reported by Kneussel et al. (1999). This difference may be partially a result of improved health of mouse cultures using modifications of age and dissociation procedure (see Materials and Methods) and the use of live cell staining. Our results are in good agreement with the subsequent reports on gephyrin -/ - retina and spinal cord (Fischer et al., 2000; Kneussel et al., 2001). Thus, it now seems likely that in most neuron types, including hippocampal neurons, gephyrin is not essential for $\mathrm{GABA}_{\mathrm{A}} \mathrm{R}$ clustering. Gephyrin contributes partially to aggregation of $\alpha 2, \alpha 3$, and $\gamma 2$, but not $\alpha 1$ or $\alpha 5$ subunits. We demonstrate here that gephyrin does not contribute to maintaining levels of surface $\mathrm{GABA}_{\mathrm{A}} \mathrm{R}$. Thus, gephyrin may function by trapping receptors, anchoring receptors, or otherwise maintaining synaptic receptor clusters rather than by inserting or stabilizing receptors in the plasma membrane. A function in receptor trapping is also supported by the observation of transient associations of surface glycine receptors with gephyrin clusters in heterologous systems (Meier et al., 2001). Whereas most models of inhibitory synaptogenesis propose that gephyrin is responsible for synaptic association of receptors, the knockout culture phenotype and wild-type artificial aggregation experiments both support the idea that $\mathrm{GABA}_{\mathrm{A}}$ Rs may actually localize to synapses first and may be responsible for synaptic association of gephyrin. We were unable to determine whether GABARs or gephyrin localize to synapses first in developing wild-type neurons, because we could consistently detect only both or neither. However, Dumoulin et al. (2000) reported in spinal cord neurons that $\mathrm{GABA}_{\mathrm{A}} \mathrm{R}$ localizes to synapses before gephyrin.

\section{Relationship of synaptic $\mathrm{GABA}_{\mathrm{A}} \mathrm{R}$ clusters and mIPSCs}

The most surprising finding in our study is the presence of functional GABAergic synapses with nearly normal mIPSCs in gephyrin-/- hippocampal neurons. The small, but significant, reduction in mean mIPSC amplitude was associated with a greater reduction in detectable surface synaptic clusters of $\mathrm{GABA}_{\mathrm{A}} \mathrm{R} \alpha 2$ and $\gamma 2$ in gephyrin $-/-$ neurons. Although we can rule out compensation by the $\alpha 1$ subunit, it may be that other $\alpha$ and $\gamma$ or $\delta$ subunits partially compensate for reduced synaptic aggregation of $\alpha 2$ and $\gamma 2$. Alternately, it is not clear how important $\mathrm{GABA}_{\mathrm{A}}$ receptor clustering is for generation of a synaptic response. Our data indicate a significant level of surface extrasynaptic $G_{A B A} R$ in both wild-type and gephyrin-/- neurons. Conceivably, a uniform synaptic and extrasynaptic receptor distribution in which synaptic clusters are not evident may still have enough receptors present to result in a functional synaptic response. Furthermore, given accumulating evidence that receptors may not be saturated by quantal release (Hajos et al., 2000), a large reduction in synaptic receptor content may result in only a small reduction in MIPSC amplitude.

In agreement with Nusser et al. (1997), we observed a correlation in the distributions of standardized mIPSC amplitude and synaptic $\mathrm{GABA}_{\mathrm{A}} \mathrm{R}$ immunofluorescence. The strength of this correlation varied among individual cells, suggesting a variation in the contribution of factors other than synaptic GABAR immunofluorescence in determining mIPSC amplitudes. Our compari- 

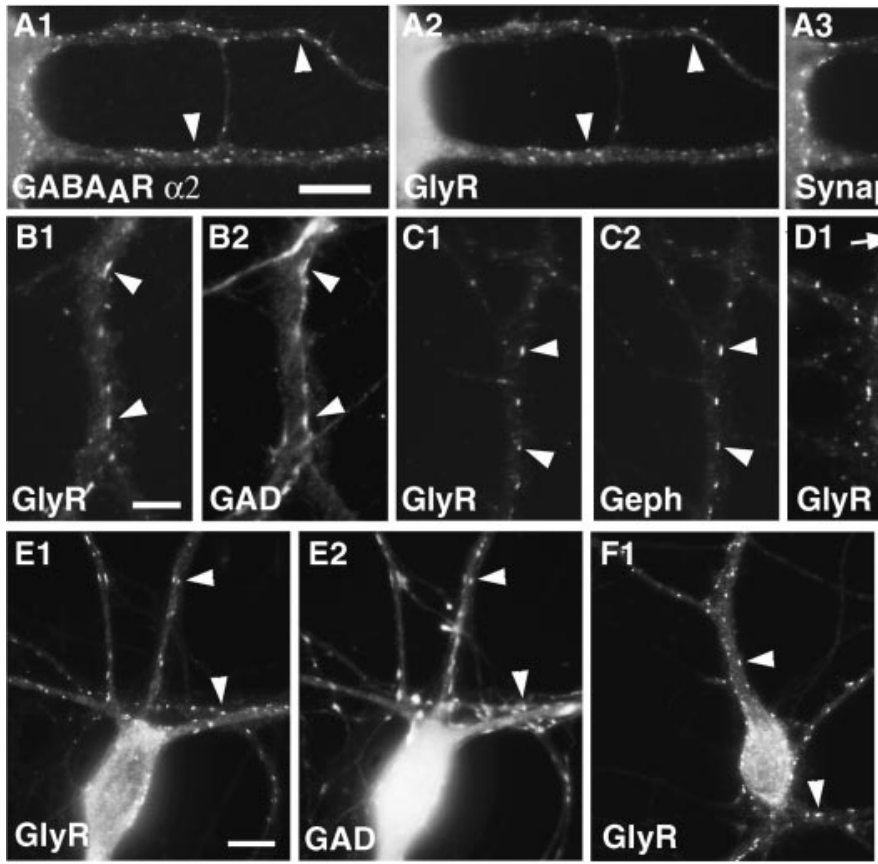
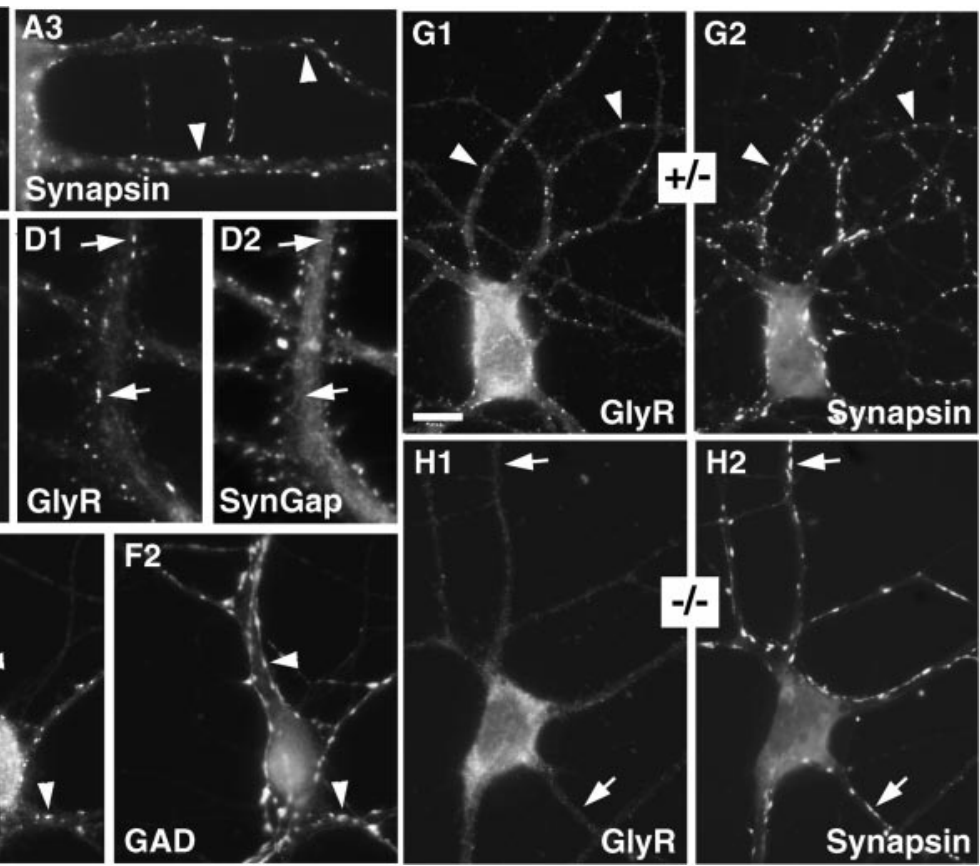

Figure 6. Clustering of glycine receptor at GABA synapses and dependence on gephyrin. Glycine receptor was detected in a subset of wild-type hippocampal neurons specifically aggregated at GABA synapses, colocalized with $G_{A B A}$ R and gephyrin opposite $G A D$ and synapsin ( $A-C$, arrowheads). Glycine receptors were not clustered at glutamatergic synapses identified by clusters of Syn $G A P$ $(D$, arrows). Glycine receptor clusters were detected on both interneurons $(E)$ and pyramidal neurons $(F)$. Whereas $44 \%$ of control gephyrin $+/-$ neurons showed clusters of glycine receptor $(G$, arrowheads), glycine receptor clustering was essentially abolished in the absence of gephyrin ( $H$, arrows; $2.5 \%$ of gephyrin $-/-$ neurons showed any clusters). Scale bars: $A, 10 \mu \mathrm{m} ; B-D, 5 \mu \mathrm{m} ;$ $E, F, 10 \mu \mathrm{m} ; G, H, 10 \mu \mathrm{m}$.

A
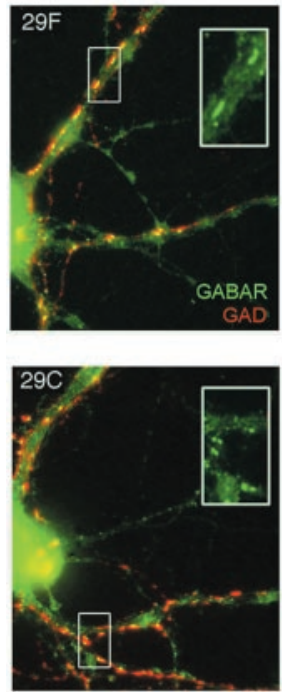

B
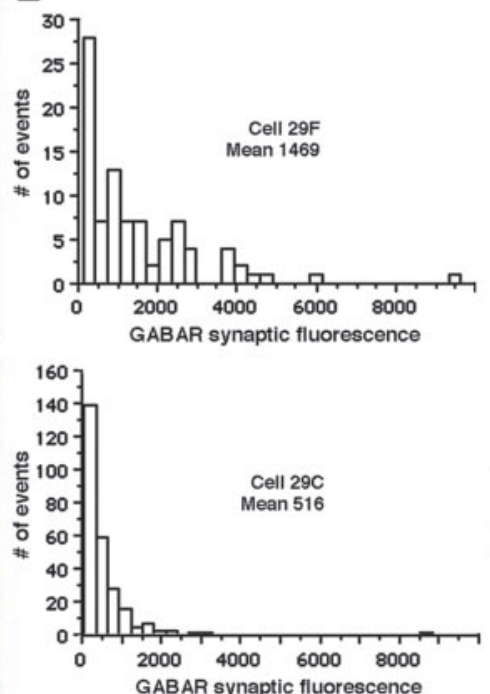
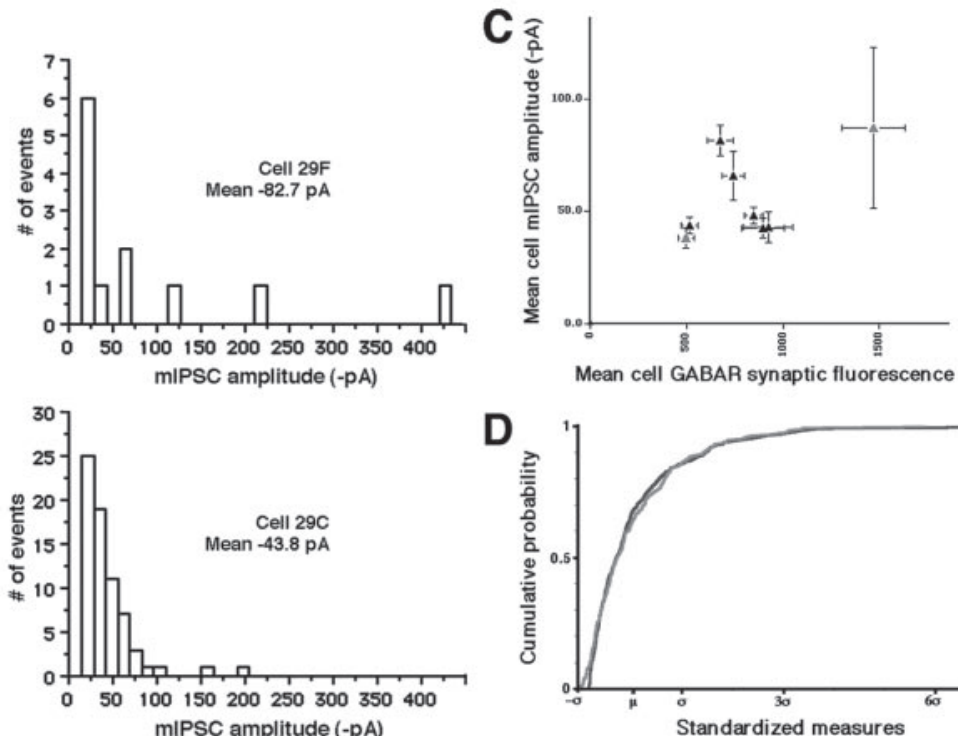

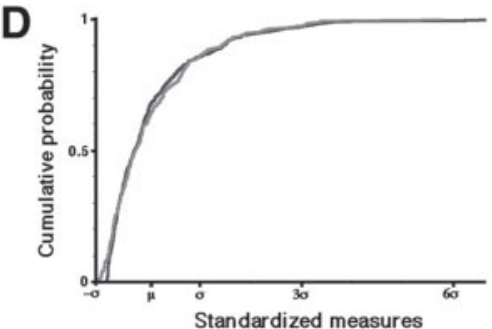

Mean cell GABAR synaptic fluorescence

Figure 7. Comparison of GABAR synaptic immunofluorescence and mIPSC amplitude distributions. Recordings of mIPSCs in wild-type hippocampal neurons were done with neurobiotin-filled electrodes, and cells were fixed, immunolabeled, and imaged in one batch for $\mathrm{GABA}_{A} R \alpha 2$ and GAD. Examples of regions of two cells recorded on the same day that exhibited larger ( $29 \mathrm{~F}$ ) or smaller (29C) synaptic GABAR clusters are shown (A). Compared with cell $29 \mathrm{C}$, cell $29 \mathrm{~F}$ exhibited a greater skew toward higher values in the distributions of integrated intensity of $G A B A_{A} R \alpha 2$ immunofluorescence per synapse (GABAR synaptic fluorescence) and of mIPS ( peak amplitude ( $B$ ). Comparison among the eight sister cells of mean cell intensity of $G A B A_{A} R \alpha 2$ per synapse versus mean cell mIPSC peak amplitude did not show a significant correlation ( $C$; correlation coefficient, 0.54 ; Spearman correlation test; $p>0.1)$. Gray triangles in $C$ represent cell 29 and $29 F$. The distributions of number of SDs of each value from the mean were not significantly difference for mIPSC amplitude values (red) and synaptic GABAR immunofluorescence values (blue) (D; data pooled from all cells; $\mathrm{K}-S ; p>0.1)$.

sons of mean cell synaptic $\mathrm{GABA}_{\mathrm{A}} \mathrm{R}$ cluster immunofluorescence and mean cell mIPSC amplitude did not show a significant correlation. However, most cells fell in a very narrow range of mean mIPSC amplitude. Furthermore, mIPSC amplitude will be influenced by factors other than the number of synaptic $\mathrm{GABA}_{\mathrm{A}} \mathrm{Rs}$.
Variability in electrotonic distance as well as vesicle filling, fusion rates, and cleft geometry are all contributors in this regard. Lim et al. (1999) found a significant correlation between mean cell gephyrin cluster immunofluorescence area and glycinergic mIPSC amplitude in anteroventral cochlear nucleus bushy cells. 


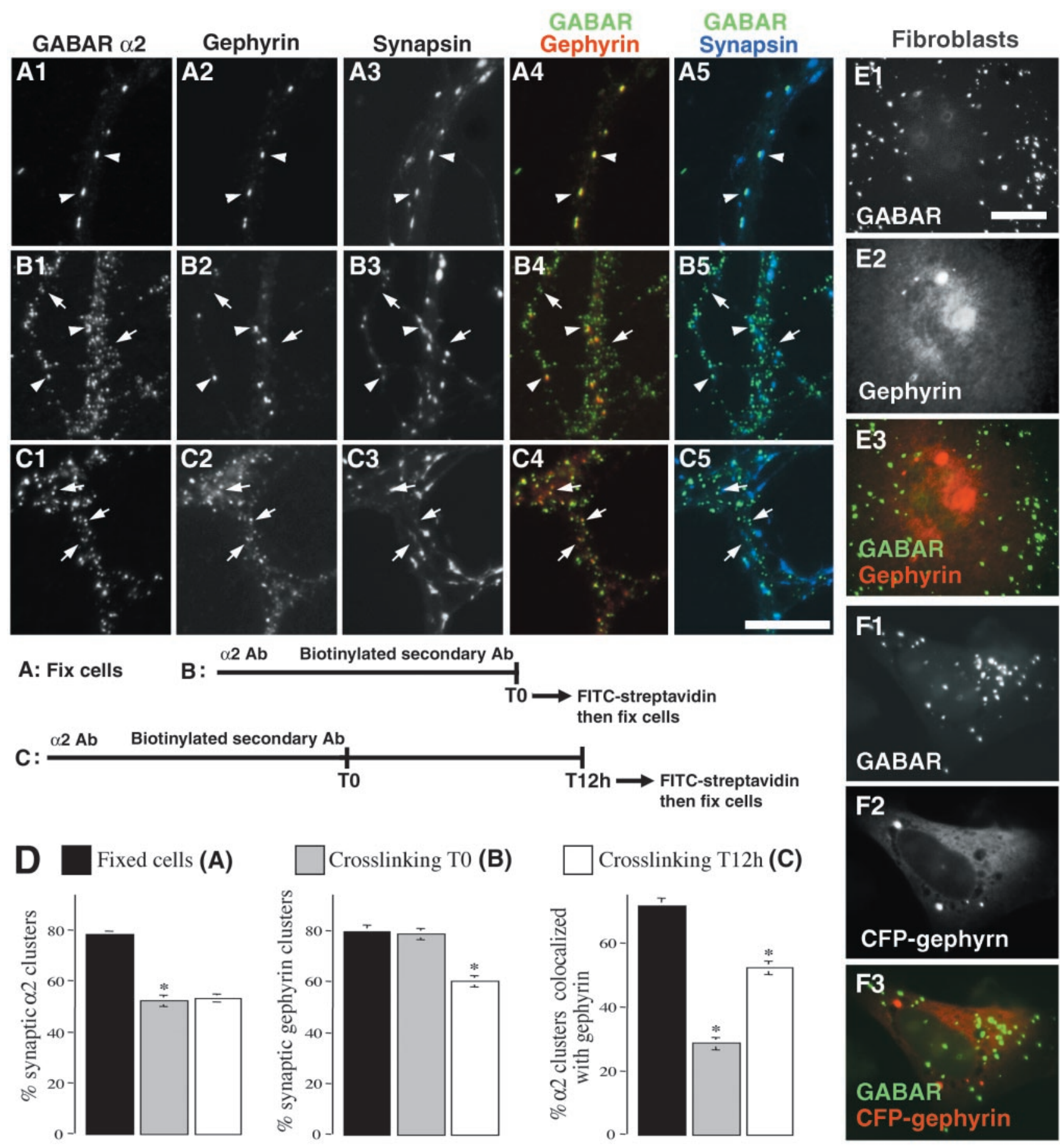

Figure 8. Coclustering of gephyrin by artifical aggregation of GABAR in neurons but not in cotransfected fibroblasts. Wild-type hippocampal neurons were fixed and then labeled with $G A B A_{A} R$ $\alpha 2 \mathrm{Ab}$, biotinylated secondary Ab, and FITC-streptavidin $(A)$, or treated live with $\mathrm{GABA}_{\mathrm{A}} \mathrm{R} \alpha 2 \mathrm{Ab}$, biotinylated secondary Ab, and FITC-streptavidin and then fixed ( $B$; cross-linking T0), or treated live with $\mathrm{GABA}_{\mathrm{A}} \mathrm{R} \alpha 2 \mathrm{Ab}$ and biotinylated secondary $A b$, incubated for $12 \mathrm{hr}$, and then treated with FITC-streptavidin and fixed $(C ;$ cross-linking T12). All neurons were immunolabeled for gephyrin ( $A 2-C 2 ; A 4-C 4$, red) and synapsin ( $A 3-C 3 ; A 5-C 5$, blue). Cross-linking at T0 resulted in formation of nonsynaptic aggregates of $G A B A_{A} R \alpha 2$ lacking gephyrin ( $B$, arrows) as well as the usual synaptic coclusters of $\mathrm{GABA}_{A} \mathrm{R} \alpha 2$, gephyrin, and synapsin (A, $B$, arrowheads). After another $12 \mathrm{hr}$, gephyrin joined the nonsynaptic aggregates of $G A B A_{A} R \alpha 2$ (C, arrows). The percentage of $G A B A_{A} R \alpha 2$ clusters localized to synapses was decreased by the cross-linking at $\mathrm{T} 0$ and $\mathrm{T} 12$, whereas the percentage of gephyrin clusters localized to synapses was decreased by the cross-linking at $\mathrm{T} 12$ but not $\mathrm{T} 0$, and the percentage of $\mathrm{GABA}_{A} \mathrm{R} \alpha 2$ clusters associated with gephyrin decreased at $\mathrm{T} 0$ and increased again at $\mathrm{T} 12\left(D ;{ }^{*} p<0.001\right)$. A similar cross-linking experiment in fibroblasts transfected with $G_{A B A_{A} R}^{R}$ YFP- $\alpha 2, \beta 3, \gamma 2$, and gephyrin or (FP-gephyrin yielded no detectable coclustering of gephyrin with GABAR $(E, F)$. Surface clustering was induced with biotinylated anti-GFP and AMCA-streptavidin (GABAR image), cells were incubated an additional $2 \mathrm{hr}$ and then fixed and immunolabeled with gephyrin antibody (E; COS-7 cells) or imaged for CFP-gephyrin (F; CH0-K1 cells). Scale bars, $10 \mu \mathrm{m}$.

Inhibitory synapses on these cells are on the soma, and there is a greater variation between cells with mean mIPSC amplitude spanning a $>100$-fold range. Site-to-site variability, perhaps corresponding to receptor cluster size, was found to be a major in- fluence on the distribution of mIPSC amplitudes (Lim et al., 2003). In hippocampal neurons, although other factors contribute, we would expect a correlation between dendritic mIPSC amplitude and $\mathrm{GABA}_{\mathrm{A}} \mathrm{R}$ cluster immunofluorescence if such a test 
could be made on a single synapse basis. Focal stimulation of single GABAergic boutons (Kirischuk et al., 1999) could be used to further probe this issue.

\section{Clustering of glycine receptors at GABA synapses in hippocampal neurons}

Strychnine-sensitive responses to application of glycine have been recorded in hippocampal neurons in culture and slice preparations (Ito and Cherubini, 1991; Chattipakorn and McMahon, 2002). Glycine receptor $\alpha 2$ and $\beta$ subunit mRNAs are also abundant in hippocampal neurons (Malosio et al., 1991; Thio et al., 2003). The majority (93-100\%) of both pyramidal cells and interneurons exhibit functional glycine receptors composed of $\alpha 2 \beta$ heteromers and/or $\alpha 2$ homomers (Chattipakorn and McMahon, 2002; Thio et al., 2003). Thus, it is not surprising to detect glycine receptors immunocytochemically on cultured hippocampal neurons. However, this is the first report indicating the selective aggregation of these glycine receptors at GABAergic synapses between hippocampal neurons. Mechanistically, we show here that glycine receptors cluster at hippocampal GABAergic synapses because of association with gephyrin. We suggest that variability in the degree of glycine receptor clustering among wild-type neurons may be a result of different expression levels of $\beta$, the gephyrin-binding subunit (Meyer et al., 1995). Neurons with primarily $\alpha 2$ homomers may correspond to those lacking apparent glycine receptor clusters, whereas neurons with high levels of $\beta$ may correspond to those with strong glycine receptor clustering.

The functional significance of glycine receptor clustering at hippocampal GABAergic synapses is not clear at present. Whereas cotransmission using both glycine and GABA is common among spinal and cerebellar neurons (Jonas et al., 1998; Dumoulin et al., 2001), hippocampal fast inhibitory transmission is completely blocked by selective $\mathrm{GABA}_{\mathrm{A}} \mathrm{R}$ antagonists, at least in vitro. It is possible in vivo that glycinergic innervation may occur from extrahippocampal pathways. Alternately, Mori et al. (2002) found that the endogenous amino acids $\beta$-alanine and taurine can tonically activate hippocampal glycine receptors. Given evidence for cross-inhibition between GABA- and glycine-mediated currents (Trombley et al., 1999; Li and Xu, 2002), glycine receptors localized to GABAergic synapses could be positioned to maximally down-modulate GABAergic transmission.

\section{Role of gephyrin at inhibitory synapses}

The surprising finding of this study is that gephyrin is not essential for GABAergic synaptic transmission and contributes only partially to aggregation of $\mathrm{GABA}_{\mathrm{A}} \mathrm{Rs}$ at hippocampal synapses. We cannot rule out the possibilities of redundancy of function or compensatory mechanisms during development. The finding by Essrich et al. (1998) that acute reduction of gephyrin clusters by antisense oligonucleotide treatment in wild-type hippocampal cultures resulted in equal reduction in clustering of $\mathrm{GABA}_{\mathrm{A}} \mathrm{R} \alpha 2$ and $\gamma 2$ does support the possibility of developmental compensation in the gephyrin $-/-$ neurons. However, arguing against these possibilities are the absence of other genes with high sequence similarity and the uncompensated defect in synaptic clustering of glycine receptors in developing gephyrin-/- hippocampal neurons (Fig. 6). Another major component of some GABA synapses is the dystrophin-associated complex (Brunig et al., 2002b; Lévi et al., 2002), containing dystrophin and $\alpha$ - and $\beta$-dystroglycan, that traditionally links the cytoskeleton to the extracellular matrix. Gephyrin was not required for localization of dystroglycan to GABA synapses, and dystroglycan was not necessary for localization of gephyrin or of $\mathrm{GABA}_{\mathrm{A}} \mathrm{R} \alpha 1, \alpha 2$, or $\gamma 2$. Thus, it seems likely that these two components, gephyrin and dystroglycan, function independently at GABAergic postsynaptic sites.

Our results raise the idea that gephyrin, like dystroglycan, may have some primary function other than clustering of $\mathrm{GABA}_{\mathrm{A}} \mathrm{Rs}$ at hippocampal synapses. A likely possibility, suggested by the results presented here, is that $\mathrm{GABA}_{\mathrm{A}} \mathrm{R}$ subunits may cluster at synapses by a gephyrin-independent mechanism and then act to recruit gephyrin. The newly localized synaptic gephyrin may then recruit glycine receptor subunits, additional $\mathrm{GABA}_{\mathrm{A}} \mathrm{Rs}$, and other signal transducing components such as RAFT1 (Sabatini et al., 1999) and the GEF collybistin (Kins et al., 2000) to the inhibitory synapse.

\section{References}

Bedford FK, Kittler JT, Muller E, Thomas P, Uren JM, Merlo D, Wisden W, Triller A, Smart TG, Moss SJ (2001) GABA(A) receptor cell surface number and subunit stability are regulated by the ubiquitin-like protein Plic-1. Nat Neurosci 4:908-916.

Brunig I, Scotti E, Sidler C, Fritschy JM (2002a) Intact sorting, targeting, and clustering of gamma-aminobutyric acid A receptor subtypes in hippocampal neurons in vitro. J Comp Neurol 443:43-55.

Brunig I, Suter A, Knuesel I, Luscher B, Fritschy JM (2002b) GABAergic terminals are required for postsynaptic clustering of dystrophin but not of GABA(A) receptors and gephyrin. J Neurosci 22:4805-4813.

Chattipakorn SC, McMahon LL (2002) Pharmacological characterization of glycine-gated chloride currents recorded in rat hippocampal slices. J Neurophysiol 87:1515-1525.

Clements JD, Bekkers JM (1997) Detection of spontaneous synaptic events with an optimally scaled template. Biophys J 73:220-229.

Danglot L, Triller A, Bessis A (2003) Association of gephyrin with synaptic and extrasynaptic GABAA receptors varies during development in cultured hippocampal neurons. Mol Cell Neurosci 23:264-278.

Dumoulin A, Lévi S, Riveau B, Gasnier B, Triller A (2000) Formation of mixed glycine and GABAergic synapses in cultured spinal cord neurons. Eur J Neurosci 12:3883-3892.

Dumoulin A, Triller A, Dieudonne S (2001) IPSC kinetics at identified GABAergic and mixed GABAergic and glycinergic synapses onto cerebellar Golgi cells. J Neurosci 21:6045-6057.

Essrich C, Lorez M, Benson JA, Fritschy JM, Luscher B (1998) Postsynaptic clustering of major GABAA receptor subtypes requires the gamma 2 subunit and gephyrin. Nat Neurosci 1:563-571.

Feng G, Tintrup H, Kirsch J, Nichol MC, Kuhse J, Betz H, Sanes JR (1998) Dual requirement for gephyrin in glycine receptor clustering and molybdoenzyme activity. Science 282:1321-1324.

Fischer F, Kneussel M, Tintrup H, Haverkamp S, Rauen T, Betz H, Wassle H (2000) Reduced synaptic clustering of GABA and glycine receptors in the retina of the gephyrin null mutant mouse. J Comp Neurol 427:634-648.

Frerking M, Borges S, Wilson M (1995) Variation in GABA mini amplitude is the consequence of variation in transmitter concentration. Neuron 15:885-895.

Goslin K, Asmussen H, Banker G (1998) Rat hippocampal neurons in lowdensity culture. In: Culturing nerve cells (Banker G, Goslin K, eds), pp 339-370. Cambridge: MIT.

Hajos N, Nusser Z, Rancz EA, Freund TF, Mody I (2000) Cell type- and synapse-specific variability in synaptic $\mathrm{GABA}_{\mathrm{A}}$ receptor occupancy. Eur J Neurosci 12:810-818.

Ito S, Cherubini E (1991) Strychnine-sensitive glycine responses of neonatal rat hippocampal neurones. J Physiol (Lond) 440:67-83.

Jonas P, Bischofberger J, Sandkuhler J (1998) Corelease of two fast neurotransmitters at a central synapse. Science 281:419-424.

Kins S, Betz H, Kirsch J (2000) Collybistin, a newly identified brain-specific GEF, induces submembrane clustering of gephyrin. Nat Neurosci 3:22-29.

Kirischuk S, Veselovsky N, Grantyn R (1999) Relationship between presynaptic calcium transients and postsynaptic currents at single $\gamma$-aminobutyric acid (GABA)ergic boutons. Proc Natl Acad Sci USA 96:7520-7525.

Kirsch J, Wolters I, Triller A, Betz H (1993) Gephyrin antisense oligonucleotides prevent glycine receptor clustering in spinal neurons. Nature 366:745-748. 
Kirsch J, Kuhse J, Betz H (1995) Targeting of glycine receptor subunits to gephyrin-rich domains in transfected human embryonic kidney cells. Mol Cell Neurosci 6:450-461.

Kittler JT, Rostaing P, Schiavo G, Fritschy JM, Olsen R, Triller A, Moss SJ (2001) The subcellular distribution of GABARAP and its ability to interact with NSF suggest a role for this protein in the intracellular transport of GABA(A) receptors. Mol Cell Neurosci 18:13-25.

Kneussel M, Betz H (2000) Receptors, gephyrin and gephyrin-associated proteins: novel insights into the assembly of inhibitory postsynaptic membrane specializations. J Physiol 525:1-9.

Kneussel M, Brandstatter JH, Laube B, Stahl S, Muller U, Betz H (1999) Loss of postsynaptic GABA(A) receptor clustering in gephyrin-deficient mice. J Neurosci 19:9289-9297.

Kneussel M, Haverkamp S, Fuhrmann JC, Wang H, Wassle H, Olsen RW, Betz H (2000) The gamma-aminobutyric acid type A receptor (GABAAR)-associated protein GABARAP interacts with gephyrin but is not involved in receptor anchoring at the synapse. Proc Natl Acad Sci USA 97:8594-8599.

Kneussel M, Brandstatter JH, Gasnier B, Feng G, Sanes JR, Betz H (2001) Gephyrin-independent clustering of postsynaptic GABA(A) receptor subtypes. Mol Cell Neurosci 17:973-982.

Lévi S, Grady RM, Henry MD, Campbell KP, Sanes JR, Craig AM (2002) Dystroglycan is selectively associated with inhibitory GABAergic synapses but is dispensable for their differentiation. J Neurosci 22:4274-4285.

Li Y, Xu TL (2002) State-dependent cross-inhibition between anionic GABAA and glycine ionotropic receptors in rat hippocampal CA1 neurons. NeuroReport 13:223-226.

Lim R, Alvarez FJ, Walmsley B (1999) Quantal size is correlated with receptor cluster area at glycinergic synapses in the rat brainstem. J Physiol (Lond) 516:505-512.

Lim R, Oleskevich S, Few AP, Leao RN, Walmsley B (2003) Glycinergic mIPSCs in mouse and rat brainstem auditory nuclei: modulation by ruthenium red and the role of calcium stores. J Physiol (Lond) 546:691-699.

Malosio ML, Marqueze-Pouey B, Kuhse J, Betz H (1991) Widespread expression of glycine receptor subunit mRNAs in the adult and developing rat brain. EMBO J 10:2401-2409.
Meier J, De Chaldee M, Triller A, Vannier C (2000) Functional heterogeneity of gephyrins. Mol Cell Neurosci 16:566-577.

Meier J, Vannier C, Serge A, Triller A, Choquet D (2001) Fast and reversible trapping of surface glycine receptors by gephyrin. Nat Neurosci 4:253-260

Meyer G, Kirsch J, Betz H, Langosch D (1995) Identification of a gephyrin binding motif on the glycine receptor beta subunit. Neuron 15:563-572.

Mori M, Gahwiler BH, Gerber U (2002) $\beta$-Alanine and taurine as endogenous agonists at glycine receptors in rat hippocampus in vitro. J Physiol (Lond) 539:191-200.

Nusser Z, Cull-Candy S, Farrant M (1997) Differences in synaptic GABA(A) receptor number underlie variation in GABA mini amplitude. Neuron 19:697-709.

Nymann-Andersen J, Wang H, Chen L, Kittler JT, Moss SJ, Olsen RW (2002) Subunit specificity and interaction domain between GABAA receptorsubunit associated protein (GABARAP) and GABAA receptors. J Neurochem 80:815-823.

Sabatini DM, Barrow RK, Blackshaw S, Burnett PE, Lai MM, Field ME, Bahr BA, Kirsch J, Betz H, Snyder SH (1999) Interaction of RAFT1 with gephyrin required for rapamycin-sensitive signaling. Science 284:1161-1164.

Sassoe-Pognetto M, Fritschy JM (2000) Mini-review: gephyrin, a major postsynaptic protein of GABAergic synapses. Eur J Neurosci 12:2205-2210.

Schroder S, Hoch W, Becker CM, Grenningloh G, Betz H (1991) Mapping of antigenic epitopes on the alpha 1 subunit of the inhibitory glycine receptor. Biochemistry 30:42-47.

Seeburg PH, Wisden W, Verdoon TA, Pritchett DB, Werner P, Herb A, Luddens H, Sprengel R, Sakmann B (1990) The GABAA receptor family: molecular and functional diversity. Cold Spring Harb Symp Quant Biol 55:29-40.

Thio LL, Shanmugam A, Isenberg K, Yamada K (2003) Benzodiazepines block $\alpha 2$-containing inhibitory glycine receptors in embryonic mouse hippocampal neurons. J Neurophysiol 90:89-99.

Trombley PQ, Hill BJ, Horning MS (1999) Interactions between GABA and glycine at inhibitory amino acid receptors on rat olfactory bulb neurons. J Neurophysiol 82:3417-3422. 